\title{
The study of VvMybA1 allele status of the indigenous grapevine varieties with non-colored berries
}

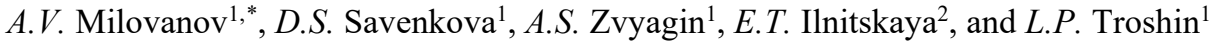 \\ ${ }^{1}$ Kuban State Agrarian University named aster I.T. Trubilin, 13 Kalinina, Krasnodar 350044 Russia \\ ${ }^{2}$ North Caucasian Federal Scientific Center of Horticulture, Viticulture, Winemaking, 40 let Pobiedy, \\ Krasnodar 350901 Russia
}

\begin{abstract}
In the present work we describe preliminary results on a partial VvMybA1 locus sequencing of rear indigenous grapevine varieties. Obtained sequences were mostly conservative and have matches in NCBI GenBank. As expected, most of them have a sequence that is typical for varieties with non-colored berries. Surprisingly, however, cultivar Jaj izium biely demonstrated structure typical for varieties with colored berries, which implies another reason for the loss of color. Obviously, Tavlinskii pozdnii and Sypun chernyj varieties had typical for colored cultivars allele structure. Some nucleotide substitutions and differences in structure of sequences were found. Furthemore, we submitted our sequences to the NCBI and here we present their accession numbers: Unji bely (MW633123), Voskeat (MW633125), Tsolikauri (MW633126), Shabash (MW633127), Terbash (MW633130), Bajan Shirei (MW633131), Katta Kurgan (MW633132), Sirgula (MW633135), Khatmi (MW633136), Jaj izium biely (N/A), Tavlinskii pozdnii (MW633139), Sypun chernyj (MW633151). All sequences, excluding Jaj izium biely genotype, were submitted to the GenBank and will be available to the public as soon as possible.
\end{abstract}

\section{Introduction}

Cultivated grapevine (Vitis vinifera L.) is one of the most common crops across the world. Since the beginning of cultivation it was bred by humanity and it resulted into biodiversity we can observe today. And one of the typical characteristics that is used for selection is berry color. As we can see, there are more than 20 thousands of grapevine genotypes that vary by different traits, but berry color was one of the first to describe them. As it is known, the color (as well as some other features) depends on the amount and composition of anthocyanins. Obviously, colored varieties accumulate them in berries, while non-colored do not do that and, therefore, do not synthesize such pigments [1].

Despite the fact that it is one of the oldest domesticated fruit crops in the world, the choice of the method of cultivation and processing of the vine depends on which hybrid,

\footnotetext{
* Corresponding author: milovanov1991@mail.ru
} 
clone and rootstock is used in production and its ampelographic properties [2]. Apparently, vegetative reproduction allowed to preserve the desired features, but simultaneously influenced the frequency of spontaneous somatic mutations observed in the field [3]. It follows that many traits were selected not only as a result of crosses, but also due to clonal selection, for example, yield, shape and compactness of a bunch, size and, of course, the color of berries [4]. As a result of hybridization and mutations we can observe varieties that have intermediate color traits, such as pink, red, yellow, etc. Of course, an important factor influencing ripening and formation of berries is the environment in which the grape plant grows $[5,6,7,8]$. But berry color is determined by genes that the genotype contains. And the metabolic pathways of anthocyanin color are regulated by the MYB genes group $[9,10$, $11,12,13]$.

Nowadays, different cultivars are described and their MYB loci are sequenced [14]. Most of them belong to Western Europe grapevine varieties, meanwhile eastern grapevine varieties (convar orientalis Negr.) and varieties of the Black Sea basin (convar. pontica Neqr.) are still not studied. Researching their genes sequences might uncover new alleles, which might be potentially useful for marker-assisted selection and genetic modification or editing. Thus we present the results of VvMybA1 alleles sequencing and their status estimation in indigenous grapevine varieties that belong to the eastern and Black Sea basin group. The alleles were partially sequenced, analyzed and submitted to the National Center for Biotechnology information.

\section{Materials and Methods}

Plant material and DNA isolation. The plant materials used in this study are presented in the Table 1. We used two colored and nine non-colored varieties that belong to the Black Sea basin and one old European variety (Unji biely).

Table 1. List of genotypes used in this study

\begin{tabular}{|c|l|c|c|c|}
\hline № & Name of genotype & Berry color & Origin & Source \\
\hline 1 & Unji biely & White & Italy & AZOSViV \\
\hline 2 & Voskeat & White & Armenia & AZOSViV \\
\hline 3 & Tsolikauri & White & Georgia & AZOSViV \\
\hline 4 & Shabash & White & Crimea & AZOSViV \\
\hline 5 & Terbash & White & Turkmenistan & AZOSViV \\
\hline 6 & Bajan Shirei & White & Azerbaijan & AZOSViV \\
\hline 7 & Katta Kurgan & White & Middle Asia & AZOSViV \\
\hline 8 & Sirgula & White & Georgia & AZOSViV \\
\hline 9 & Khatmi & White & Dagestan & AZOSViV \\
\hline 10 & Jaj izium biely & White & Dagestan & AZOSViV \\
\hline 11 & Tavlinskii pozdnii & Dark-blue & Dagestan & AZOSViV \\
\hline 12 & Sypun chernyj & Dark-blue & Don territory & AZOSViV \\
\hline
\end{tabular}

Firstly, fresh leaves were dried using Martin Christ Lyophilizer (Martin Christ), than grinded by metal balls at micro tubes with rotor mill GT200 Grinder (Green Research Scientific). DNA extraction and purification was carried out using DNeasy Plant Mini Kit (QIAGEN). Estimation of isolated DNA amount and quality was performed using IMPLEN NP80 nanophotometer (IMPLEN).

Molecular markers and PCR conditions. To carry out PCR and isolate alleles of the VvMybA1 gene, markers described by Azuma et al. [15] were used. A PCR mixture with a volume of $25 \mu$, including: $20 \mathrm{ng}$ of DNA, $200 \mathrm{mM}$ DNTP, $0.2 \mathrm{mM}$ of each primer and 1 unit of DNA polymerase. The following parameters were used for PCR: initial denaturation $95{ }^{\circ} \mathrm{C}-3$ minutes, then 35 cycles $94{ }^{\circ} \mathrm{C}-30$ seconds; $57{ }^{\circ} \mathrm{C}-30$ seconds; $72{ }^{\circ} \mathrm{C}-30$ 
seconds; and $72{ }^{\circ} \mathrm{C}-10$ minutes for final elongation. Verification of the PCR results for the presence of expected fragments was carried out in $2 \%$ TAE agarose gel, separation of amplification products in a horizontal electrophoresis chamber (Helicon) with the following parameters: $15 \mathrm{~min}, 150 \mathrm{~V}$ and $150 \mathrm{~A}$.

Isolation and purification of PCR products; Sanger sequencing. PCR fragments were separated on a $2 \%$ agarose gel in TAE buffer. After that, the obtained fragments were cut out from the gel plate and isolated using the Cleanup Standart kit (Evrogen RU). The concentration of the PCR sample was measured using IMPLEN NP80 nanophotometer and was brought to a volume of $6 \mu \mathrm{l}$ with deionized water, containing the purified PCR fragment in the amount of $30 \mathrm{ng} / \mu \mathrm{l}$. Sequencing was carried out by Evrogen RU company using forward and reverse PCR primers [15].

Analysis of nucleotide sequences. Initial analysis for the compliance with expected result was performed by searching the sequence in the NCBI database using BLAST [16]. The obtained DNA and protein sequences were aligned using standard parameters in the ClustalO program, VIENNA formats (for aligning in fasta format) [17]. Aligned sequences were analyzed using the MView [18] interface. Phylogenetic relationships between the studied amino acid sequences were established using the MEGA7 program [19] using the Maximum Likelihood method [20], with the Jones-Taylor-Thornton model [21] (999 bootstrap).

\section{Results}

The results indicate that PCR using selected primers showed amplicons with a similar size. Regarding the fact that cultivars have different berry color, we assumed that they have different structure. These amplicons were sequenced using Sanger method with forward and reverse primers. After that, sequences were aligned using ClustalO program and visualized with MView (Figure 1). Alignment of obtained sequences showed us that alleles have mostly similar structure. However, two remarkable properties were noted: uncolored genotypes have longer alleles and Jaj izium biely has insertion (111 base pairs long) in the middle of the sequence. Interestingly, NCBI BLAST identified this insertion as a part of VvMybA1 gene alleles of Sirch, Shiraz and Yaghuti varieties, which all have black berries (unpublished data: GenBank accessions: KY346963.1, KY406229.1 and KY406228.1). Additionally, unique SNP was discovered in Sypun chernyj allele structure. But the strong berry color indicates it as a neutral mutation. 


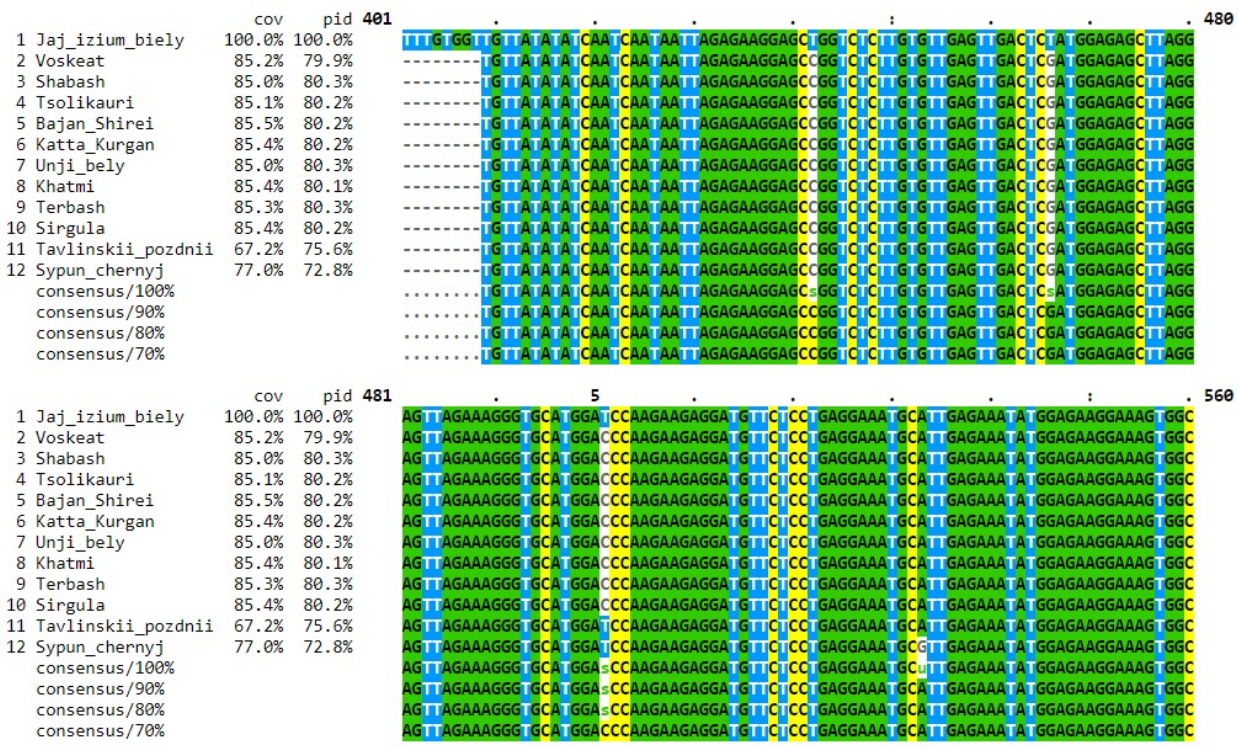

Fig. 1. Alignment of sequences.

To identify the nature of berry color absence in these varieties we conducted BLAST search to compare our sequences with GenBank accessions. Thus the results of identification are presented in the Table 2.

Table 2. Results of identification of studied grapevine VvMybA1 alleles.

\begin{tabular}{|c|c|c|c|}
\hline № & Name & Match & $\begin{array}{l}\text { GenBank } \\
\text { accession }\end{array}$ \\
\hline 1 & Unji biely & $\begin{array}{l}\text { V. vinifera, retrotransposon Gret1, } \\
\text { VvmybA1 }\end{array}$ & AB442010.1 \\
\hline 2 & Voskeat & $\begin{array}{l}\text { V. vinifera, retrotransposon Gret } 1 \text {, } \\
\text { VvmybA1 }\end{array}$ & AB442010.1 \\
\hline 3 & Tsolikauri & $\begin{array}{l}\text { V. vinifera, retrotransposon Gret } 1 \text {, } \\
\text { VvmybA1 }\end{array}$ & AB442010.1 \\
\hline 4 & Shabash & $\begin{array}{l}\text { V. vinifera, retrotransposon Gret1, } \\
\text { VvmybA1 }\end{array}$ & AB442010.1 \\
\hline 5 & Terbash & $\begin{array}{l}\text { V. vinifera, retrotransposon Gret } 1 \text {, } \\
\text { VvmybA1 }\end{array}$ & AB442010.1 \\
\hline 6 & Bajan Shirei & $\begin{array}{l}\text { V. vinifera, retrotransposon Gret } 1 \text {, } \\
\text { VvmybA1 }\end{array}$ & AB442010.1 \\
\hline 7 & Katta Kurgan & $\begin{array}{l}\text { V. vinifera, retrotransposon Gret } 1, \\
\text { VvmybA1 }\end{array}$ & AB442010.1 \\
\hline 8 & Sirgula & $\begin{array}{l}\text { V. vinifera, retrotransposon Gret } 1, \\
\text { VvmybA1 }\end{array}$ & AB442010.1 \\
\hline 9 & Khatmi & $\begin{array}{l}\text { V. vinifera, retrotransposon Gret1, } \\
\text { VvmybA1 }\end{array}$ & AB442010.1 \\
\hline 10 & Jaj izium biely & $\begin{array}{l}V . \text { vinifera, MybA1 gene, mybA1-SUB } \\
\text { allele }\end{array}$ & GQ890360.1 \\
\hline 11 & Tavlinskii pozdnii & $\begin{array}{l}V . \text { vinifera, cultivar Panje Arus, MybA1 } \\
\text { gene }\end{array}$ & KY406230.1 \\
\hline 12 & Sypun chernyj & $\begin{array}{l}V . \text { vinifera, cultivar Alphonse Lavalle, } \\
\text { MybA1 gene, mybA1-ALF allele }\end{array}$ & DQ403722.1 \\
\hline
\end{tabular}

As expected, BLAST results indicated that most of the varieties with white berries have 
insertion of Gret1 retrotransposon that block normal transcription of VvMybA1 gene. And this block results in the loss of berry color. Surprisingly, Jaj izium biely showed similarity with mybA1-SUB allele that leads to normal expression and the presence of color. This indicates that the loss of color in this genotype has another basis, for example SNP in VvMybA2, which requires additional studies. Then we conducted a tree construction to study phylogenetic relationship between studied sequences.

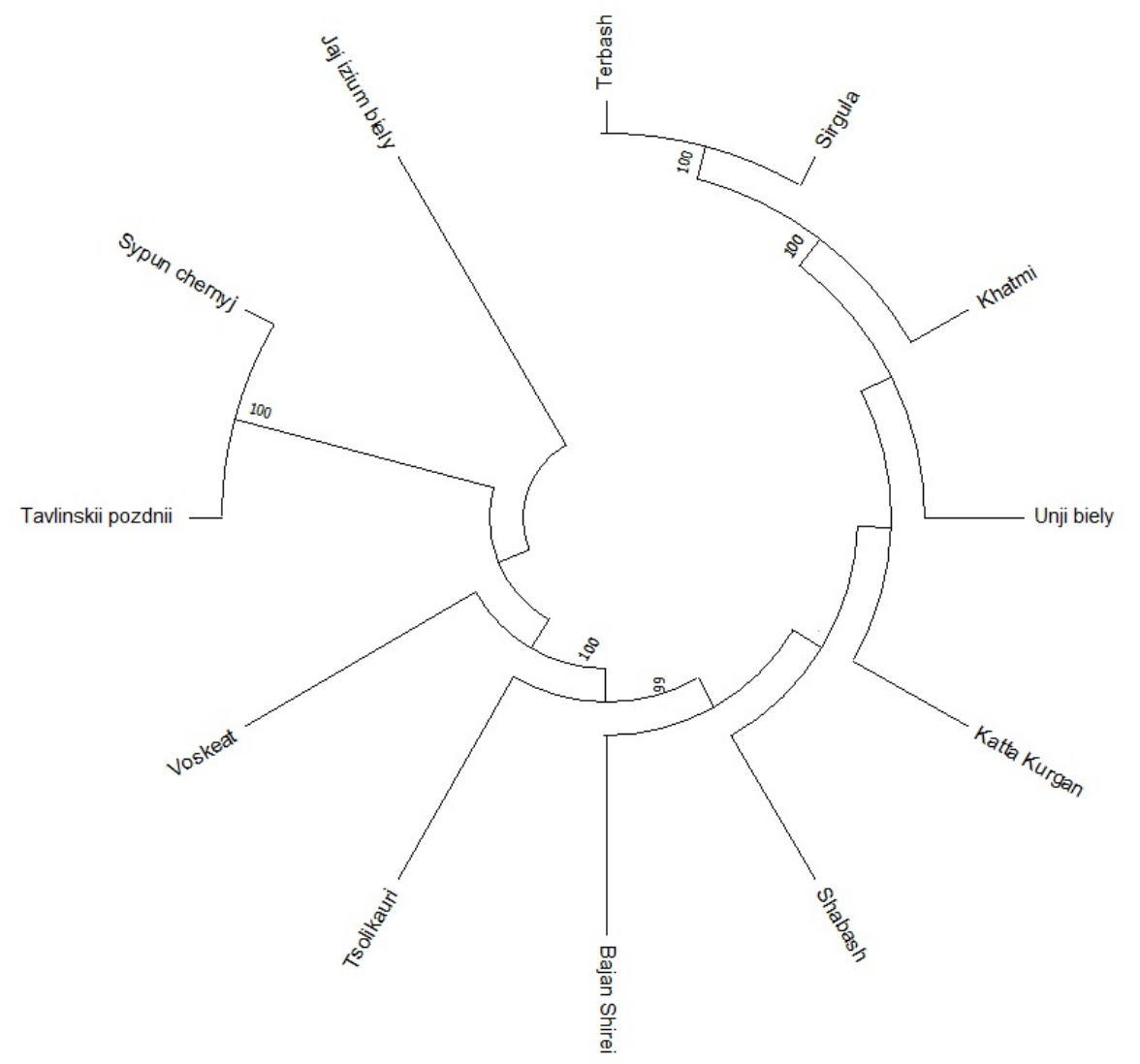

Fig. 2. UPGMA clusterization of alleles based on their partial sequences.

As we can see, clusterization of alleles distributed genotypes according to the structure of their sequences. Most of them were placed together confirming similar structure of alleles without expression. Reference "red" genotypes were placed together. And unique genotype was placed along. Bootstraps indicate that positions seem to be correct.

\section{Discussion}

Apparently, the results indicate mostly conservative structure of studied alleles, which is not surprising in context of previous studies [14]. Anyway, BLAST search showed us individual differences between queries and subjects. Furthermore, we submitted our sequences to the NCBI and here we present their accession numbers: Unji bely 
(MW633123), Voskeat (MW633125), Tsolikauri (MW633126), Shabash (MW633127), Terbash (MW633130), Bajan Shirei (MW633131), Katta Kurgan (MW633132), Sirgula (MW633135), Khatmi (MW633136), Jaj izium biely (N/A), Tavlinskii pozdnii (MW633139), Sypun chernyj (MW633151). Thus all genotypes were submitted to the GenBank (excluding Jaj izium biely) and will be available to the public as soon as possible for further studying. Also, we can conclude that gene structure of most varieties without anthocyanin suspect intervention of Gret1 retrotransposon. This subsequently leads to the loss of color and was previously shown for another cultivars [15]. Interestingly, colored varieties did not show a unique gene structure too and had similarities to known genotypes such as Panje Arus (Tavlinskii pozdnii) and Alphonse Lavalle (Sypun chernyj).

\section{Conclusion}

VvMybA1 alleles of twelve indigenous varieties from Russian ampelographic collection (Unji biely, Voskeat, Tsolikauri, Shabash, Terbash, Bajan Shirei, Katta Kurgan, Sirgula, Khatmi, Jaj izium biely, Tavlinskii pozdnii, Sypun chernyj) are identified for the first time. The size of alleles was nearly close to each other. But the structure was different, because SNPs and different patterns were observed. Alignment of alleles revealed similarities and differences in their structures along with the groups (genotypes with colored and noncolored berries). As expected, most of them have typical configuration for non-colored genotypes that have insertion of Gret1 retrotransposon. Surprisingly, cultivar Jaj izium biely demonstrated structure typical for colored varieties, which implies another reason for the loss of color. Varieties with colored berries such as Tavlinskii pozdnii and Sypun chernyj, obviously, had alleles that colored cultivars have. Additionally, unique SNP was discovered at Sypun chernyj allele, but the presence of berry color indicates it as a neutral mutation.

\section{Acknowledgment}

This work was supported by the grant of Russian Foundation for Basic Research and Administration of the Krasnodar Territory, grant № 19-44-233003.

\section{References}

1. P. K. Boss, C. Davies, S. P. Robinson, Plant molecular biology, 32 (3), 565-569 (1996)

2. J. J. Swanepoel, J. M. Southey, South African Journal of Enology and Viticulture 10 (1), 23-28 (1989)

3. C. Van Leeuwen, J. P. Roby, V. Alonso-Villaverde, K. Gindro, Journal of agricultural and food chemistry, 61 (1), 19-24 (2012)

4. N. Torres, N. Goicoechea, F. Morales, M. C. Antolín, Crop and Pasture Science, 67 (9), 961-977 (2016)

5. S. Guidoni, A. Ferrandino, V. Novello, American Journal of Enology and Viticulture, 59 (1), 22-29 (2008)

6. A. Anesi, M. Stocchero, S. Dal Santo, M. Commisso, S. Zenoni, S. Ceoldo, B. Battista Tornielli, T. Siebert, M. Herderich, M. Pezzotti, F. Guzzo, BMC plant biology, 15 (1), 191 (2015)

7. G. E. Pereira, J. P. Gaudillere, C. van Leeuwen, G. Hilbert, M. Maucourt, C. Deborde, A. Moing, D. Rolin, Analytica Chimica Acta, 563 (1-2), 346-352 (2006) 
8. S. Dal Santo, S. Zenoni, M. Sandri, G. De Lorenzis, G. Magris, E. De Paoli, G. Di Gaspero, C. Del Fabbro, M. Morgante Lucio, B. Grossi, M. Fasoli, P. Zuccolotto, G. Battista, M. Pezzotti, The Plant Journal, 93 (6), 1143-1159 (2018)

9. A Azuma, S Kobayashi, N. Mitani, M. Shiraishi, M. Yamada, T. Ueno, A. Kono, H. Yakushiji, Y. Koshita, Theoretical and Applied Genetics, 117 (6), 1009-1019 (2008)

10. A. Azuma, Y. Udo, A. Sato, N. Mitani, A. Kono, Y. Ban, H. Yakushiji, Y. Koshita, S. Kobayashi, Theoretical and Applied Genetics, 122 (7), 1427-1438 (2011)

11. S. Kobayashi, M. Ishimaru, K. Hiraoka, C. Honda, Planta, 215 (6), 924-933 (2002)

12. S. Kobayashi, N. Goto-Yamamoto, H. Hirochika, Science, 304 (5673), 982-982 (2004)

13. A. R. Walker, E. Lee, J. Bogs, D. A. McDavid, M. R. Thomas, S. P. Robinson, The Plant Journal, 49 (5), 772-785 (2007)

14. D. Lijavetzky, L. Ruiz-García, J. A. Cabezas, M. T. De Andrés, G. Bravo, A. Ibáñez, J. M. Martínez-Zapater, Molecular Genetics and Genomics, 276 (5,) 427-435 (2006)

15. A. Azuma, S. Kobayashi, H. Yakushui, M. Yamada, N. Mitani, A. Sato, Vitis, 46 (3), 154 (2007)

16. S. McGinnis, T. L. Madden, Nucleic acids research, 32 (suppl_2), 20-25 (2004)

17. F. Sievers, D. G. Higgins Current protocols in bioinformatics, 48(1), 3-13 (2014)

18. N P Brown, C. Leroy, C. M. Sander, Bioinformatics, 14 (4), 380-381 (1998)

19. S. Kumar, G. Stecher, K. Tamura, Molecular biology and evolution, 33 (7), 1870-1874 (2016)

20. G. N. Murshudov, A. A. Vagin, E. J. Dodson, Acta Crystallographica, 53 (3), 240-255 (1997)

21. D. T. Jones, W. R. Taylor, J. M. A. Thornton, Biochemistry, 33 (10), 3038-3049 (1994) 